\title{
Pemberdayaan Perempuan Desa Pondok Melalui Kelompok Wirausaha Anyaman Lidi
}

\author{
Mahfuzi Irwan \\ Program Studi Pendidikan Masyarakat, Universitas Negeri Medan. \\ Jl. William Iskandar Pasar V Medan Estate 20371. Email: \\ mahfuziirwan@gmail.com
}

\begin{abstract}
Abstrak
Penelitian ini bertujuan untuk mendeskripsikan pemberdayaan perempuan, inovasi dalam membuat kerajinan anyaman, dan faktor-faktor pendukung serta penghambat keberhasilan pemberdayaan perempuan di Desa Pondok Sei Piring. Jenis penelitian adalah penelitian kualitatif metode studi kasus. Sumber data yang diteliti adalah ketua kelompok wirausaha pondok, pengelola rumah kerajinan, dan pengrajin anyaman. Pengumpulan data melalui wawancara, observasi serta dokumentasi. Analisis data dilakukan dengan pengumpulan data, reduksi data, penyajian data, dan kesimpulan. Instrumen yang digunakan adalah pedoman wawancara, pedoman observasi, dan dokumentasi. Keabsahan data dilakukan dengan triangulasi data, sumber dan teknik. Hasil penelitian menunjukkan bahwa proses pemberdayaan pengrajin anyaman di Rumah Kerajinan Pulau Raja yaitu melakukan pelatihan, melakukan pendampingan, dan evaluasi. Inovasi yang dilakukan yaitu inovasi proses dan produk yang menghasilkan jenis anyaman dan metode pemasaran kekinian yang dapat diaplikasikan pada kerajinan anyaman. Faktor pendukungnya ialah adanya integrasi dana desa, lokasi desa dan bentuk rumah, serta pusat pelatihan perempuan. Sedangkan faktor penghambat yaitu minimnya keterlibatan warga, semakin menipisnya stok generasi penerus dan persaingan harga.
\end{abstract}

Kata Kunci: desa pondok, kerajinan anyaman, pemberdayaan perempuan

\begin{abstract}
This study aims to describe women's empowerment, innovation in making woven crafts, and the factors supporting and inhibiting the success of women's empowerment in Pondok Sei Piring Village. This type of research is a qualitative case study method. The data sources studied were the head of the family welfare association, the manager of the craft house, and the weaving craftsmen. Collecting data through interviews, observation and documentation. Data analysis was performed by data collection, data reduction, data presentation, and conclusions. The instruments used were interview guidelines, observation guidelines, and documentation. The data validity was done by triangulating data, sources and techniques. The results showed that the empowerment process of weaving craftsmen at the Pulu Raja Craft House was conducting training, mentoring, and evaluation. The innovations made are process and product innovations that produce types of webbing and contemporary marketing methods that can be applied to woven crafts. Supporting factors are the integration of village funds, village location and housing, as well as a women's training center. Meanwhile, the inhibiting factors are the lack of citizen involvement, the depletion of future generations' stocks and price competition.
\end{abstract}

Keywords: pondok village, woven crafting, women's empowerment 


\section{PENDAHULUAN}

Desa Pondok merupakan suatu istilah atau sebutan bagi desa yang berdasarkan letak geografisnya berada di sekeliling perkebunan. Perkebunan yang dimaksud adalah Perkebunan kelapa sawit. Selain itu istilah desa Pondok juga diberikan karena mayoritas warga desanya adalah seorang pekerja perkebunan di sebuah pabrik kelapa sawit, namun hal yang paling unik ialah seluruh tempat tinggal warga masyarakatnya memiliki kesamaan bentuk menyerupai pondok. Seperti Desa Sei Piring yang ada di Sumatra Utara tepatnya di Kabupaten Asahan. Desa ini merupakan satu dari tiga desa pondok yang terdapat di kecamatan Pulau Rakyat, Kab. Asahan. Menjadi pusat perhatian karena desa pondok ini berbeda dari kebanyakan desa yang terdapat di kecamatan tersebut. Yakni, dikarenakan desa pondok dikelilingi oleh perkebunan kelapa sawit, yang tentunya juga menjadi pusat pencaharian warga desa setempat.

Seperti penjelasan dari (Sanjaya \& Budiwirman, 2019) bahwa desa Pondok tergantung pada bagaimana memanfaatkan dan mengelola potensi yang terdapat di desa tersebut termasuk dari keragaman masyarakatnya, ketersediaan sumber daya alam yang ada di dalamnya hingga pengelolaan tersebut menghasilkan nilai tambah desa. Di Indonesia, keragaman kultur dan budaya menjadi satu-satunya pembeda antara desa yang satu dengan yang lainnya karena jika berbicara letak geografis perbedaannya tidak jauh berbeda sehingga keragaman budaya ini yang menjadi keunikan bagi setiap desa.

Menurut (Hamzah \& Irfan, 2018; Jumiarni, 2020) tingkat pengembangan desa Pondok sebagai produsen kerajinan anyaman lidi dapat dikategorikan menjadi tiga tahap, yaitu sebagai berikut. Pertama, adanya potensi yang ditandai dengan: (1) Keterbatasan dari sumber daya manusia dalam memanfaatkan potensi alam yang tersedia; (2) Minimnya atau masih sedikitnya kunjungan masyarakat luar seperti wisatawan (3) Kesadaran masyarakat dalam mengembangkan potensi yang ada masih kurang. 
Kedua, Berkembang, pada tingkat ini, sebuah desa Pondok yang produktif ditandai dengan: (1) Dikenalnya desa oleh masyarakat luar atau wisatawan; (2) Adanya pengembangan infrastruktur yang ditandai dengan adanya fasilitas yang mendukung dalam memproduksi anyaman lidi; (3) Terbentuknya komunitas lokal yang dipadati oleh pengrajin anyaman lidi; (4) Kesadaran masya- rakat akan potensi alam di desa pondok sudah mulai tumbuh; (5) Masih membutuhkan bantuan dari pihak terkait (pemerintah, swasta).

Ketiga, pada tingkat ini, sebuah desa ditandai dengan: (1) Kesadaran masyarakat desa pondok dalam memenuhi pengembangan potensi alam yang tersedia; (2) Desa telah menjadi pusat penghasil kerajinan anyaman lidi yang paling dicari dan diminati hasilnya (3) Fasilitas infrastruktur dan fasilitas perkebunan memadai; (4) Komunitas ini mandiri dan mampu untuk mengelola bisnis dari hasil atau limbah perkebunan secara mandiri (sumber daya manusia, produk, organisasi, dll.); (5) Mampu memasarkan dengan membentuk jaringan luas antar desa, kecamatan serta tingkat kabupaten dalam mempromosikan hasil produksi komunitas; (6) Dapat menjadi desa percontohan dari desa yang lainnya (Kirowati \& Setia, 2018).

Secara konseptual menurut (Suharto, 2014) pemberdayaan menunjuk pada kemampuan orang khususunya kelompok rentan dan lemah sehingga mereka memiliki kekuatan atau kemampuan dalam (a) memenuhi kebutuhan dasarnya sehingga mereka memilki kebebasan (freedom), dalam arti bukan hanya bebas mengemukakan pendapat melainkan bebas dari kelaparan, kebodohan, dan kesakitan; (b) menjangkau sumber-sumber produktif yang memungkinkan mereka dapat meningkatkan pendapatannya dan memperoleh barang-barang dan jasa-jasa yang mereka perlukan; dan (c) berpartisipasi dalam proses pembangunan dan keputusan-keputusan yang mempengaruhi mereka.

Desa Pondok Sei Piring merupakan salah satu tempat yang sangat tepat untuk diadakan program pemberdayaan masyarakat. Karena desa 
Pondok Sei Piring sangat butuh diberdayakan, apalagi berada di lingkungan masyarakat yang punya kesempatan untuk memenuhi kebutuhan dasarnya, menjangkau sumber-sumber produktif dalam hal ini ketersediaan sumber alam kelapa sawit sehingga berpeluang membangkitkan partisipasi masyarakat dalam pembangunan. Menurut (Suyanto \& Pudjianto, 2015) umumnya masyarakat mengapresiasi jika ada sekelompok masyarakat yang berkontribusi demi desa mereka apalgi sampai kontribus tersebut membawa dampak yang positif bagi seluruh masyarakat desa. Pada masa reformasi pemerintahan desa sekarang ini, umumnya pemerintahan desa Pondok tengah berlomba- lomba untuk membuat kegiatan pemberdayaan bagi warga desa. Ada yang membuat pemberdayaan berdasarkan potensi local yang terdapat di sekitar desa apakah itu berbentuk sumber daya alam, tradisi, sejarah dan mungkin halhal lain yang terkadang tidak disadari keberadannya. Tetapi beberapa desa secara kreatif membuat sebuah desa dengan sebutan khas seperti kampung ramah anak, kampung cyber, Pondok kuliner, Pondok edukasi, PKK yang fokus pada program kesehatan dan sebagainya (Harahap \& Rizal, 2019; Jamaluddin et al., 2019). Seperti halnya di Sumatera Utara, ada banyak jenis desa Pondok yang kegiatan pemberdayaannya sudah ada, hampir semua jenis desa Pondok ada di provinsi ini, baik yang sudah lama terbentuk maupun yang baru saja dibentuk, mulai dari program desa keluarga berencana, program pemberdayaan remaja, dan pemberdayaan perempuan.

Kecamatan Pulau Rakyat merupakan salah satu kecamatan yang ada di Kabupaten Asahan yang memiliki berbagai sentra kerajinan. Ada dua desa yang sudah dinobatkan sebagai desa Pondok yang memiliki sentra kerajinan, dua diantaranya adalah desa yang memiliki potensi kerajinan anyaman limbah lidi kelapa sawit, yaitu di Desa Orika Pulau Rakyat dan Desa Sei Piring. Di Desa Pondok Orika, terdapat sekitar 35 alat anyaman lidi yang disediakan oleh pengelola industri, namun yang digunakan hanya ada 3-7 alat anyaman saja yang digunakan. Ini 
dikarenakan persaingan yang ketat, dan semakin berkurangnya warga sekitar yang berminat untuk menekuni kegiatan menganyam lidi di desa Orika. Para ibu rumah tangga pun tidak lagi tampak di rumah kerajinan anyaman lidi ini, para ibu rumah tangga di desa ini lebih tertarik untuk bekerja di tempat lain dan mengurusi pekerjaan rumah tangga dari pada mengasah keterampilan dan memiliki usaha sendiri, padahal di Desa Orika sudah ada potensi anyaman dari limbah lidi kelapa sawit yang berkualitas dan terkenal sampai ke luar Pulau Jawa. Hingga saat ini, masih ada masyarakat khususnya perempuan yang berminat dan tertarik untuk membuat anyaman dari lidi kelapa sawit di Orika. Walaupun para pembuat piring lidi ini hanya ada 3 orang yang aktif dan sudah berusia lanjut, namun mereka masih bersemangat untuk melanjutkan perjuangan untuk membuat piring lidi.

Beberapa tahun yang silam, Desa Orika memiliki berbagai rumah kerajinan, tetapi karena persaingan yang ketat, minat terhadap anyaman lidi semakin berkurang, secara perlahan desa ini kehilangan rumah produksi anyaman lidi dan hanya tertinggal satu rumah produksi saja. Di rumah produksi ini dikelola oleh dua orang yang usianya sudah tidak lagi muda, namun masih bersemangat untuk menekuni dan melanjutkan usaha kerajinan mereka. Hasil produksi yang mereka hasilkan berupa sapu lidi dan anyaman berbentuk piring. Mengenai hal ini, (Rahman \& Budiywono, 2018)berpendapat bahwa saat ini yang menjadi penghambat kerajinan anyaman adalah minimnya sumber daya manusia yang berminat untuk menganyam khususnya pada generasi muda. Apabila hal ini terjadi, maka akan dikhawatirkan kerajinan anyaman akan punah karena tidak ada lagi yang mau dan terampil menganyam.

Tidak jauh dari Desa Pondok Orika, di Desa Pondok Sei Piring, ada 11 industri kerajinan anyaman yang masih aktif dengan berbagai macam jenis kerajinan seperti kerajinan anyaman lidi kelapa sawit. Industriindustri ini terdapat di beberapa rumah warga dalam satu desa. Oleh karena di desa ini banyak yang memiliki rumah produksi kerajinan, 
desa ini disebut dengan pusat kerajinan. Kualitas dari hasil produksi di desa ini pun sangat tinggi dan sudah mengekspor ke berbagai wilayah. Di desa Sei Piring juga terdapat kerajinan anyaman lidi dengan menggunakan alat tradisional. Alat ini juga menarik wisatawan lokal yang berkunjung untuk mencoba menggunakan alat ini, tentunya dipandu oleh karyawan yang bekerja di rumah kerajinan ini. Pengrajin yang ummumnya para ibu rumah tangga ini menganyam berbagai bentuk aneka piring dan wadah yang kualitas sangat baik. Harapannya, desa ini memiliki peningkatan pendapatan dengan berbagai potensi yang sudah dimiliki, dan memiliki keberlanjutan untuk masa yang akan datang.

Tujuan dari penelitian ini untuk mengetahui secara mendalam proses pemberdayaan perempuan pengrajin anyaman lidi kelapa sawit di Desa Pondok Sei Piring, mengetahui secara mendalam mengenai inovasi yang sudah dilakukan masing-masing industri kerajinan di desa Pondok Sei Piring, menggali faktor-faktor pendukung dan penghambat Desa Sei Piring masih terus ada dengan industri kerajinan sampai sekarang ini.

\section{METODE PENELITIAN}

Jenis penelitian ini adalah penelitian kualitatif dengan menggunakan metode studi kasus. Waktu penelitian dilaksanakan pada agustus hingga september 2019 dan bertempat di 2 rumah industri kerajinan yang termasuk dalam sentra kerajinan Desa Pondok Sei Piring yaitu Rumah Ketua PKK (Portu Seni) dan Rumah Anyam.

Sumber data yang diteliti adalah ketua PKK Desa Pondok Sei Piring sekaligus sebagai ketua kelompok wirausaha pondok, 2 orang pengelola dari 2 rumah kerajinan yang berbeda, dan 2 pengrajin tenun dari rumah kerajinan yang berbeda. Pengumpulan data melalui wawancara yang mendalam, observasi serta dokumentasi. Analisis data dilakukan dengan pengumpulan data, reduksi data, penyajian data, dan kesimpulan. Instrumen yang digunakan ada- lah pedoman wawancara, pedoman observasi, dan dokumentasi. Keabsahan data dilakukan dengan 
triangulasi data, sumber dan teknik.

\section{HASIL DAN PEMBAHASAN}

\section{Proses Pemberdayaan Perempuan di Desa Pondok Sei Piring}

Proses pemberdayaan perempuan di Desa Pondok Sei Piring melewati berbagai tahapan dan proses yang cukup panjang karena ada proses memberdayakan masyarakat yang awalnya kurang berdaya. Jika mengacu pada hasil penelitian yang telah dilakukan oleh (Sulistyani \& Wulandari, 2017), proses pemberdayaan mengarah pada serangkaian langkah-langkah yang ditempuh dalam mengubah masyarakat yang kurang atau belum berdaya menuju keberdayaan. Jika dicermati lebih dalam menurut (Lippitt, 1958; Wilson, 1996) sebuah pemberdayaan masyarakat melewati beberapa tahapan, tahapan tersebut terbagi atas 7 (tujuh) kegiatan pokok diantaranya; (1) Penyadaran dan identifikasi masalah, yaitu kegiatan yang dilakukan untuk menyadarkan masyarakat tentang "keberadaannya", baik sebagai anggota masyarakat maupun individu kemudian menunjukkan adanya masalah yaitu kondisi keadaan sumber daya (manusia, alam, budaya, sarana prasarana) memprihatinkan; (2) Tahap transformasi kemampuan berupa wawasan pengetahuan, kecakapan keterampilan agar terbuka wawasan dan memberikan keterampilan dasar sehingga dapat mengambil peran di dalam pembangunan; (3) Tahap peningkatan peran atau partisipasi, yaitu kemauan untuk mengikuti dan mengambil bagian dalam kegiatan pemberdayaan sehingga kompetensi untuk melakukan perubahan meningkat.

Berdasarkan hasil penelitian yang telah dilakukan, proses pemberdayaan berawal dari proses penyadaran yang dilakukan oleh pihak luar perusahaan pengolahan kelapa sawit. Pada awalnya pihak luar tersebut datang ke desa Sei Piring dan meminta pengrajin anyaman lidi setempat untuk membuat keranjang dengan menggunakan daun kelapa sawit, karena pada waktu tahun tahun 2010 terjadi penurunan harga sawit yang sangat menyulitkan perusahaan sehingga pihak luar perusahaan berfikir untuk membuat tas dengan menggunakan bahan-bahan yang 
berasal dari limbah sawit atau bagian-bagian dari kelapa sawit yang sudah tidak digunakan. Seperti yang diungkapkan oleh Kusnidar dalam wawancara yang telah dilakukan, bahwa "setelah produk kerajinan sudah jadi, produk tersebut dijual oleh pihak luar perusahaan ke daerah asal mereka dan menjadi barang yang paling dicari dan diminati banyak orang, setelah itu kerajinan keranjang daun sawit pun diproduksi secara massal. Kemudian banyak pembeli-pembeli yang datang dari luar daerah mencari barang-barang yang terbuat dari limbah-limbah dan bagian pohon sawit, seperti tas dari daun sawit, piring dari lidi sawit lalu dijual ke berbagai daerah di asahan.

Dengan adanya kontribusi dari pihak luar desa, yang merupakan tokoh masyarakat di desa sei piring, membuat masyarakat sadar bahwa perkebunan kelapa sawit dan kerajinannya merupakan salah satu yang bisa dijadikan sumber pendapatan ekonomi masyarakat di Desa Sei Piring dan memiliki prospek ke depan yang dapat meningkatkan taraf perekonomian masyarakat Sei Piring. Keberadaan kerajinan anyaman lidi kelapa sawit dapat membantu proses pemberdayaan para pengrajin di Desa Pondok Sei Piring. Untuk mengetahui proses pemberdayaan tersebut, maka dapat dianalisis pula tahapan- tahapannya sebagai berikut.

\section{Tahap Penyadaran dan Identifikasi Masalah}

Pada tahap ini, proses yang terjadi yaitu adanya kesadaran masyarakat khususnya para ibu rumah tangga untuk merubah kondisi mereka agar menjadi lebih baik lagi karena selama mereka tinggal di desa tersebut mereka hanya menikmati nafkah dari suaminya yang bekerja di perusahaan perkebunan kelapa sawit yang nilainya pas-pasan. Oleh karena itu, masyarakat melalui kepala desa dan PKK membentuk kelompok wirausaha agar kegiatan masyarakat dapat dengan mudah diorganisir. Setelah membentuk kelompok wirausaha, ibu rumah tangga pengurus kelompok wirausaha ini membangkitkan kepedulian masyarakat terhadap potensi sumber daya alam seperti perkebunan kelapa sawit dan kerajinan anyaman lidi didesanya sebagai upaya untuk 
membangun kembali eksistensi kerajinan anyaman lidi kelapa sawit. Kelompok Wirausaha ini juga diberi nama Kelompok Wirausaha Pondok.

Kegiatan yang sudah dilakukan pengelola rumah kerajinan anyaman lidi yang sudah terdaftar di kelompok wirausaha tersebut yaitu mengikuti pelatihan yang diadakan oleh pemerintah desa Sei Piring dan kerja sama desa dengan berbagai universitas atau perguruan tinggi di Sumatera Utara sehingga dapat menunjang pengetahuan pengelola rumah kerajinan dan dapat menerapkannya.

\section{Tahap Transformasi Kemampuan}

Pada tahap ini, pengrajin yang telah mengikuti pelatihan dari pemerintah desa dan berbagai kegiatan pengabdian masyarakat dari perguruan tinggi mulai mengimplementasikan hasil dari pelatihan tersebut untuk mentransferkan ilmu yang didapat kepada pengrajin yang lain. Kelompok Wirausaha Pondok berperan sebagai fasilitator antara para pengrajin dengan konsumen yang membeli atau memesan produk anyaman lidi kelapa sawit serta membuka kelas singkat melalui kegiatan kursus atau pelatihan yang ditujukan bagi siapa saja yang ingin belajat menganyam lidi kelapa sawit.

\section{Tahap Peningkatan Peran atau Partisipasi}

Pada tahap peningkatan peran atau partisipasi ini, para perempuan pengrajin anyaman lidi kelapa sawit melatih kemampuannya di rumah mereka masing-masing, sampai muncul kemandirian. Kemandirian tersebut membuat pengrajin anyaman lidi dapat berinisiatif sehingga memunculkan ide-ide baru, melahirkan pola dan bentuk anyaman lidi yang menarik, serta melakukan inovasi-inovasi dalam membuat kerajinan anyaman lidi, dan lebih berani dalam membuat inovasi produk anyaman lidi kelapa sawit yang baru . Misalnya, sebelumnya belum ada kreasi piring untuk berbagai hidangan, namun sekarang sudah ada dibuat kreasi piring dan wadah hidangan lain seperti buah-buahan anyaman 
yang terbuat dari lidi kelapa sawit.

Lebih lanjut, proses pemberdayaan yang terjadi di desa pondok sei piring yang melibatkan Kelompok Wirausaha Pondok melewati berbagai tahapan sebagai berikut.

\section{Melakukan Pelatihan}

Proses pelatihan ini melibatkan pemerintah desa sei piring dan beberapa perguruan tinggi, kegiatan yang dilakukan yaitu sebagai berikut. Pertama, melakukan pelatihan bagi beberapa anggota dan perangkat kelompok wirausaha untuk mengikuti pelatihan-pelatihan yang diadakan oleh pemerintah desa sei piring, maupun dari desa lainnya. Kemudian hasil dari pelatihan tersebut diterapkan dan dikembangkan di desa Pondok Sei Piring. Kedua, mensosialisasikan kegiatan kepada para penenun dan anggota kelompok wirausaha untuk ikut berpartisipasi dalam setiap kegiatan yang diadakan oleh kelompok wirausaha pondok. Kegiatan yang dilakukan yaitu turut membantu para wisatawan lokal yang berkunjung untuk mengikuti kelas pelatihan membuat kerajinan atau yang mau belajar menganyam dan membantu memasarkan produk anyaman ke berbagai konsumen.

\section{Melakukan Pendampingan}

Pada proses pendampingan, pengurus kelompok wirausaha mendampingi para pengrajin anyaman dalam setiap pelaksanaan kegiatan di sentra kerajinan, baik itu ketika sedang berinteraksi dengan para pengunjung maupun ketika sedang menganyam dengan alat tradisional.

\section{Melakukan Evaluasi}

Pada proses ini, pengurus kelompok wirausaha mengadakan pertemuan dengan anggota kelompok wirausaha dan meminta bantuan pendampingan dosen Pendidikan luar sekolah dari perguruan tinggi untuk mengevaluasi kegiatan yang sudah berlangsung, sekaligus mengidentifikasi permasalahan yang terjadi selama kegiatan kerajinan 
berlangsung agar dapat ditemukan dan dicarikan solusinya bersama. Untuk mengevaluasi hasil anyaman yang dibuat, dilakukan pada saat pengrajin membuat anyaman.

Merunut hasil dari wawancara dan pembahasan tersebut, dapat disimpulkan bahwa proses pemberdayaan perempuan pengrajin anyaman lidi dimulai dari mengikuti kegiatan pelatihan, kemudian melakukan pendampingan, lalu melakukan evaluasi sebagaimana yang sudah dijelaskan di atas.

\section{Inovasi Proses dan Produk Kerajinan di Desa Pondok Sei Piring}

Upaya yang dilakukan untuk keberlanjutan sentra kerajinan ini yaitu dengan membuat design-design atau jenis-jenis anyaman terbaru. Inovasi yang sudah dilakukan agar produk kerajinan bisa bersaing dengan kerajinan-kerajinan lain yaitu Berdasarkan hasil penelitian yang sudah dilakukan dapat diungkap bahwa inovasi kerajinan anyaman lidi kelapa sawit di desa Pondok Sei Piring ini yaitu inovasi proses dan inovasi produk. Sebagaimana yang telah dijelaskan bahwa Inovasi proses merupakan implementasi produksi yang ditingkatkan secara signifikan atau produksi baru atau metode pengantaran /pengiriman. Hal ini mencakup perubahan-perubahan yang penting dalam teknik, peralatan, dan perangkat lunak dan inovasi produk merupakan peningkatan kualitas produk ataupun dengan menyediakan bentuk produk yang beragam dan menggunakan bahan lain yang juga lebih murah serta ramah lingkungan, seperti biasanya anyaman lidi tidak menggunakan cat berwarna, ditangan para perempuan desa pondok sei piring produk anyaman tadi bisa bernilai lebih.

Proses produksi anyaman lidi kelapa sawit mengalami berbagai perubahan dari tahun ketahun sehingga proses produksi semakin lama semakin cepat dan dengan cara yang lebih efisien. Dalam proses menganyam para pengrajin yang notabennya adalah ibu rumah tangga desa pondok menggunakan media pembelajaran online untuk mengupgrade keterampilan mereka agar produksi dapat lebih cepat 
diselesaikan bahkan dalam memasarkan produknya para pengrajin melalui kelompok wirausaha pondok menggunakan metode kekinian seperti online shop. Dilain hal, produk-produk di Desa Pondok Sei Piring telah mengalami banyak perubahan dari tahun ke tahun, sehingga untuk anyaman seperti piring lidi tidak lagi berwarna alami seperi kuning kecoklatan namun sudah dapat diprduksi dengan berbagai warna yang menarik. Bahkan kehalusan dari anyaman semakin bagus kualitasnya karena menggunakan tambahan cat pengkilap yang sekaligus dapat memperindah anyaman lidi. Dari sisi jenis produknya juga banyak tercipta, tidak hanya piring lidi yang digunakan oleh rumah makan, café atau restoran saja namun juga tersedia produk hidangan buah dan case/sarung toples makanan. Inovasi pun akan terus menerus dikembangkan terutama dari segi proses dan produk kerajinan anyaman sehingga produksi kerajinan akan dapat terus berlangsung dan membawa dampak yang signifikasn terhadap perekonomian masyarakat desa.

Berdasarkan hasil pemaparan di atas, dapat dipahami bahwa inovasi proses dan inovasi produk pada kerajinan anyaman menghasilkan berbagai jenis maupaun design-design futuristik serta dalam menjual produk tersebut para pengrajin melalui kelompok wirausaha sudah merambah pasar yang sangat luas karena menggunakan metode kekinian yaitu online shop.

Faktor Pendukung dan Penghambat Pemberdayaan Perempuan Desa Pondok

\section{Faktor Pendukung}

Integrasi Dana Desa

Faktor pendukung yang bersumber dari dana desa maksudnya adalah adanya penyelenggaraan kegiatan-kegiatan masyarakat yang dapat mengundang warga dari desa lain bahkan berbagai daerah. Kegiatankegiatan tersebut seperti perlombaan, acara-acara kebudayaan serta pelatihan-pelatihan yang diselenggarakan besar-besaran menggunakan dana desa. Hal tersebut secara tidak langsung dapat membuat desa Pondok 
Sei Piring tetap eksis dan semakin diminati meskipun sebagian dari kegiatan tersebut diselenggarakan tidak rutin setiap hari dan hanya pada saat- saat tertentu, namun setiap kerajinan memiliki peluang dibeli saat kegiatan tersebut berlangsung dengan membuka bazar hasil kerajinan atau secara tersirat menjadi model peralatan yang dipajang di meja-meja tamu sebagai wadah hidangan. Ini juga kesempatan besar bagi desa Pondok Sei Piring untuk menunjukkan hasil kerajinan anyaman yang menjadi ciri khas desa Pondok ini agar menjadi semakin berkembang.

\section{Lokasi Desa dan Bentuk Rumah}

Selain itu, faktor pendukung lainnya yaitu lokasi desa pondok sei piring yang dikelilingi oleh perkebunan sawit namun juga berada tepat dipinggir jalan lintas sumatera. Lokasi ini sangat menguntungkan bagi desa pondok sehingga dengan musah terekspos oleh siapapun yang melintas di jalan lintas sumatera. Apalagi ditambah dengan bentuk rumah masyarakat desa yang tersusun rapi dan seragam dari cat jalan yang menghubungkan rumah warga hingga tatanan pekarangan rumahnya menjadikan desa ini punya memiliki faktor pendukung yang unik.

\section{Pusat Pelatihan Perempuan}

Tingginya angka ibu rumah tangga di Desa Pondok menjadi dasar perencanaan program pemerintah desa untuk menjadwalkan berbagai macam pelatihan. Hal tersebut dikarenakan dana desa yang diperoleh tidak banyak yang bisa disalurkan untuk keperluan infrasrtuktur desa dikarenakan mayoritas tanah yang digunakan warga masyarakat merupakan milik dari perusahaan perkebunan bukan milik negara. Sehingga program desa yang paling menonjol adalah pelatihan atau pemberdayaan masyarakat khususnya kaum perempuan. Namun hal yang menjadi nilaitambah ialah program pemberdayaan perempuan yang dilakukan pemerintah desa tidak luput dari evaluasi yang rutin dilakukan desa dengan mitranya demi mendapatkan masukan terbaik untuk programnya, hal ini senada dengan pendapat (Irwan, 2017) yang mengungkapkan bahwa evaluasi program harus senantiasa dilakukan oleh 
siapa saja yang merencanakan program demi keberlangsungan program itu dikemudian hari. Jadi, tidak heran kalau setiap melintas di kantor desa pondok ini selalu terlihat ada kegiatan yang dilakukan.

\section{Faktor Penghambat}

\section{Keterlibatan Warga}

Faktor utama yang dapat menghambat perkembangan desa Pondok ini yaitu tidak semua warga memiliki kesadaran untuk mengembangkan desanya sendiri sebagaimana pendapat (Hulu et al., 2018) yang mengatakan bahwa pengembangan desa akan terhambat apabila warganya tidak mau atau kurang terlibat dalam pembangunan desa. Hal ini terjadi pada Desa Pondok sebagai pusat kerajinan anyaman. Permasalahan tersebut disebabkan hanya beberapa ibu rumah tangga saja yang dapat merasakan keuntungan langsung dari desa Pondok ini, sehingga masyarakat belum menyadari keuntungan dari adanya pembangunan desa Pondok.

Pihak kelompok wirausaha pondok sudah berupaya untuk mensosialisasikan tentang desa Pondok sebagai pusat kerajinan anyaman pada setiap kali ada pertemuan, namun tidak semua warga mau untuk mengembangkan desa Pondok dengan alas an punya kesibukan yang berbeda-beda. Apabila semua warga bisa memiliki pemahaman yang sama, tujuan atau visi misi yang sama, maka harapannya pengembangan desa Pondok Sei Piring sebagai pusat kerajinan anyaman ini jadi lebih optimal karena adanya keterlibatan dari seluruh masyarakat di desa Pondok Sei Piring.

\section{Generasi Penerus}

Generasi penerus sekarang sudah tidak berorientasi lagi pada kegiatan mengayam. Karena para ibu rumah tangga pengrajin sudah tidak melihat lagi harapan pada anyaman lidi yang sudah mulai berkurang peminatnya meskipun anak mereka sebagian sudah bisa menganyam. Pengrajin anyaman lidi banyak yang menganggur dikarenakan usia yang sudah tidak muda lagi dan generasi yang dapat menenun sekarang ini 
sudah mulai berkurang karena di desa ini usia mudanya didominasi oleh laki-laki sehingga punya minat dan cara yang berbeda pula dalam meningkatkan pendapatan keluarganya. Selain itu, pengrajin merasa permintaan sudah tidak sebanyak yang dulu sehingga kehilangan semangat untuk menganyam kembali. Kendala lain yang terjadi pada saat proses produksi dikarenakan pengrajinnya lebih banyak yang berusia lanjut dan umumnya anak-anak para pengrajin yang perempuan sebenarnya bisa menganyam lidi, namun dikarenakan sudah menikah dan ikut suami maka hal tersebut tidak bisa dipaksakan.

\section{Persaingan Harga}

Adapun faktor penghambat selanjutnya yaitu ada pada persaingan harga produk anyaman lidi keapa sawit yang berasal dari luar daerah. Banyaknya produk yang serupa masuk ke berbagai daerah di Sumatera Utara dengan harga yang jauh lebih murah disbanding harga jual para pengrajin di Desa Pondok Sei Piring. Persainganh harga tersebut menurut (Putridiani \& Suryono, 2019) diakrenakan adanya perubahan harga yang ada di AFTA (ASEAN Free Trade Area) yang berpengaruh pada industry kerajinan di Indonesia, produk-produk Cina juga banyak yang masuk ke Indonesia sehingga berpengaruh pada produk lokal. Selain perubahan harga pada AFTA, persaingan harga pun terjadi ke konsumen anyaman lidi yang lebih memilih untuk membeli produk yang murah tanpa melihat sisi kualitasnya. Singkatnya, ada juga yang memproduksi kerajinan anyaman lidi seperti wadah hidangan makanan, vas bunga, case toples dengan harga yang lebih murah namun dengan kualitas yang sederhana. Ini mengakibatkan konsumen lebih memilih produk yang lebih murah tersebut daripada produk yang dihasilkan di desa Pondok Sei Piring.

\section{SIMPULAN}

Proses pemberdayaan perempuan pengrajin anyaman lidi kelapa sawit melalui kelompok wirausaha di Sentra Kerajinan desa Pondok Sei Piring yaitu: (a) Melakukan pelatihan, dengan melakukan pelatihan bagi beberapa anggota dan pengurus kelompok wirausaha, kemudian hasil dari 
pelatihan tersebut diterapkan dan dikembangkan di Desa Pondok Sei Piring, serta mensosialisasikan kepada para pengrajin anyaman dan anggota kelompok wirausaha untuk ikut berpartisipasi dalam setiap kegiatan yang diadakan oleh pemerintah desa. (b) Melakukan pendampingan, dengan mendampingi para pengrajin anyaman dalam setiap pelaksanaan kegiatan di sentra kerajinan, baik itu ketika sedang berinteraksi dengan para pengunjung maupun ketika sedang menganyam (c) Evaluasi, dengan mengevaluasi kegiatan yang berlangsung, sekaligus mengidentifikasi permasalahan-permasalahan yang terjadi selama kegiatan kerajinan berlangsung agar dicarikan solusinya bersama. Untuk mengevaluasi hasil tenun yang dibuat, dilakukan pada saat pengrajin membuat anyaman. Inovasi yang sudah dilakukan agar masing-masing rumah kerajinan mampu bersaing di Desa Pondok Sei Piring yaitu inovasi proses dan inovasi produk. Dalam proses menganyam para pengrajin yang notabennya adalah ibu rumah tangga desa pondok menggunakan media pembelajaran online untuk mengupgrade keterampilan mereka agar produksi dapat lebih cepat diselesaikan bahkan dalam memasarkan produknya para pengrajin melalui kelompok wirausaha pondok menggunakan metode kekinian seperti online shop. Dari sisi jenis produknya juga banyak tercipta, tidak hanya piring lidi yang digunakan oleh rumah makan, café atau restoran saja namun juga tersedia produk hidangan buah dan case/sarung toples makanan. Faktor pendukung Desa Pondok Sei Piring masih terus ada dengan industri kerajinannya sampai sekarang ini di antaranya ialah adanya integrasi dana desa, lokasi desa dan bentuk rumah, pusat pelatihan perempuan. Sedangkan faktor penghambat dalam perkembangan desa Pondok Sei Piring ini yaitu kurangnya keterlibatan warga, generasi penerus dan persaingan harga.

\section{DAFTAR PUSTAKA}

Alqauri, M. H. (2017). Implementasi program pemberdayaan ekonomi masyarakat melalui usaha ternak kambing lembaga dompet dhuafa 
waspada di Desa Sidomulyo Kecamatan Binjai Kabupaten Langkat. Universitas Islam Negeri Sumatera Utara.

Hamzah, A. S., \& Irfan, M. (2018). Local Wisdom Based Tourist Village Sade Lombok Organization within the Framework of Sustainable Tourism Development. 282(4000), 129-132. https://doi.org/10.2991/icblt-18.2018.31

Harahap, J., \& Rizal, F. (2019). Peran Pemberdayaan Kesejahteraan Keluarga Dalam Pemberdayaan Wanita Di Desa Simatahari Kecamatan Kota Pinang Kabupaten Labuhanbatu Selatan. Jurnal Pemberdayaan Masyarakat, 7(2), 112. https://doi.org/10.37064/jpm.v7i2.5827

Hulu, Y., Harahap, R. H., \& Nasutian, M. A. (2018). Pengelolaan Dana Desa dalam Pemberdayaan Masyarakat Desa. Jupiis: Jurnal Pendidikan Ilmu-Ilmu Sosial, 10(1), 146. https://doi.org/10.24114/jupiis.v10i1.9974

Irwan, M. (2017). Evaluasi Program Pelatihan Pengolahan Limbah Kertas Semen pada Pusat Kegiatan Belajar Masyarakat ( PKBM ) Cahaya Kota Binjai Abstrak Kata Kunci : program, evaluasi, pelatihan, keterampilan , PKBM An evaluation of Cement Paper Waste Processing Training. Jurnal Pendidikan Dan Pemberdayaan Masyarakat (JPPM), 4(2), 121-132.

Jamaluddin, Y., Fitriani, F., Safrida, S., \& Warjio, W. (2019). Strategi dan Model Pemberdayaan Masyarakat Miskin di Sumatera Utara. Jurnal Administrasi Publik: Public Administration Journal, 9(1), 21. https://doi.org/10.31289/jap.v9i1.2231

Jumiarni, D. (2020). MASYARAKAT SADAR LINGKUNGAN IMPLEMENTATION OF TAKAKURA COMPOSTING FOR FARMERS IN TANJUNG TERDANA VILLAGE PONDOK KUBANG BENGKULU TENGAH , AS AN EFFORT TO EMPOWER ENVIRONMENTALLY CONCIOUS COMMUNITY Oleh : 18(1), 63-70.

Kirowati, D., \& Setia, L. D. (2018). PENGEMBANGAN DESA MANDIRI MELALUI BUMDES DALAM MENINGKATKAN KESEJAHTERAAN MASYARAKAT DESA ( Studi Kasus :Desa Temboro Kecamatan Karas Kabupaten Magetan). Jurnal AKSI (Akuntansi Dan Sistem Informasi), 2(1), 
15-24. https://doi.org/10.32486/aksi.v2i1.213

Lippitt, R. (1958). a comparative study of principles and techniques. Harcourt, Brace.

Putridiani, S. A., \& Suryono, Y. (2019). Pemberdayaan pengrajin tenun. JPPM (Jurnal Pendidikan Dan Pemberdayaan Masyarakat), 6(2), 161-169.

Rahman, A., \& Budiywono, E. (2018). Pemanfaatan Lidi Daun Kelapa Menjadi Handycraft Dalam Bentuk Anyaman Piring Lidi di Desa Purwoasri Kecamatan Tegaldlimo Kabupaten Banyuwangi. Loyalitas: Jurnal Pengabdian Kepada Masyarakat, 1(1), 11-20.

Sanjaya, I. F., \& Budiwirman, B. (2019). Bentuk dan fungsi Tale Haji dalam acara pelepasan jamaah haji di Desa Pondok Agung Kecamatan Pondok Tinggi Kota Sungai Penuh. Jurnal EDUCATIO: Jurnal Pendidikan Indonesia, 5(2), 76. https://doi.org/10.29210/120192351

Suharto, E. (2014). Membangun masyarakat, memberdayakan rakyat: kajian strategis pembangunan kesejahteraan sosial dan pekerjaan sosial. PT.Refika Aditama.

Sulistyani, A. T., \& Wulandari, Y. (2017). Proses Pemberdayaan Masyarakat Desa Sitimulyo Kecamatan Piyungan Kabupaten Bantul Dalam Pembentukan Kelompok Pengelola Sampah Mandiri (KPSM). Jurnal Pengabdian Kepada Masyarakat (Indonesian Journal of Community Engagement), 2(2), 146-162. https://doi.org/10.22146/jpkm.27024

Suryono, Y., \& Tohani, E. (2016). Inovasi Pendidikan Nonformal. Graha Cendikia.

Suyanto, S., \& Pudjianto, B. (2015). Pemberdayaan Masyarakat Menuju Desa Sejahtera (Studi Kasus Di Kabupaten Sragen). Sosio Konsepsia, 5(1), 340354. https://doi.org/10.33007/ska.v5i1.164

Wilson, T. (1996). The empowerment manual. Gower. 